\title{
Promotion Strategy On Decisions On Using J\&T Express Services, Pekanbaru
}

\author{
Erfa Okta Lussianda ${ }^{1}$, Munawir ${ }^{2}$ \\ ${ }^{1}$ Department of Management, Sekolah Tinggi Ilmu Ekonomi Persada Bunda, Indonesia \\ ${ }^{2}$ Department of Information Management, AMIK Indonesia, Indonesia \\ 'erfachianda10@gmail.com, ${ }^{2}$ munawir@amikindonesia.ac.id
}

\section{Article Info}

Article history:

Received September 292020

Revised December 282020

Accepted January 22021

\section{Keywords:}

Startegic, Promotion, Decision, Use of Service, Consumer Purchases

\begin{abstract}
In this study discusses the promotion of the Decision on the Use of $\mathrm{J} \& \mathrm{~T}$ Express Services at PT Garuda Ekspress Nusantara in the city of Pekanbaru. The method used is using simple linear regression with the result $\mathrm{Y}=5.878$ $+0.925 \mathrm{X}$. From this equation it can be explained that koonstanta $(\mathrm{Y}=5.878$ $+0.925 \mathrm{X}$, from the equation can be explained that, the constant (a) is 5.878 stating that there is no the promotion of the use decision of 5.878. The regression coefficient of 0.925 states that each addition of one promotion unit it is predicted that the decision to use will increase by 0.925 . This is because there is a relationship between promotion and decision to use services. The hypothesis testing is done by comparing the $\mathrm{t}$ statistic value with $\mathrm{t}$ table at alpha $5 \%$ and degree of freeom $(\mathrm{df})=96-2=94$. So that the thable value is 1,986 . It is known that $t$ count is 12,892 while $t$ table is 1,986 (tcount 12,892 $>$ ttable 1,986). $\mathrm{t}$ table, then $\mathrm{t}$ count $>\mathrm{t}$ table so the result is $\mathrm{H} 0$ is rejected, meaning the promotion has a role significant influence on Decision Use of $\mathbf{J}$ \& T Express services at PT Garuda Ekspress Nusantara Pekanbaru.
\end{abstract}

Corresponding Author:

Erfa Okta Lussianda.

Departement Management,

Sekolah Tinggi Ilmu Ekonomi Persada

Jalan Diponegoro No. 42. Pekanbaru, Riau, Indonesia

Email : erfachianda10@gmail.com

\section{INTRODUCTION}

Goods delivery services are increasingly prevalent and much favored by the community, because with this shipping service it can make it easier for consumers to ship goods. A shipping service is a company engaged in goods delivery services, the process of which is moving goods from one place to another. Delivery of goods occurs because of a sale and purchase transaction of goods. PT Garuda Ekspress Nusantara is a shipping service company that was founded in 2015 under the name J\&T Express Pekanbaru expedition. Since the establishment of this shipping service, PT Garuda Nusantara (J\&T Express) has used several promotions including free onsite shuttle promotions without any conditions, free call centers, in collaboration with e-commerce businesses that are distributed in the form of advertisements, brochures, banners, Promotions that have been carried out by PT Garuda Nusantara (J\&T Express) are still not maximal, which can be seen in the development of the use of Freight Forwarding Services at PT Garuda Ekspress Nusantara, which can be seen in table 1 below:

Table 1. Development of the Use of J\&T Express Freight Forwarding at PT Garuda Ekspress Nusantara 2015 $-2017$

\begin{tabular}{cccc}
\hline Year & Development of the Use of J\&T Express & Turnover & Percentage\% \\
\hline 2015 & 37,080 receipts & Rp. 723,060,000, - & - \\
2016 & 33,840 receipts & Rp. 642,960,000, - & $-11.1 \%$ \\
2017 & 34,560 receipts & Rp. 656,640,000, - & $2.1 \%$ \\
\hline
\end{tabular}

Source: PT Garuda Ekspress Nusantara 
From the table above, it can be seen that the realization of goods delivery services carried out by PT Garuda Ekspress Nusantara in 2015 amounted to 37,080 receipts, in 2016 it decreased by 33,840 receipts and in 2017 there was an increase that was not maximal with the number of receipts 34,560. The decrease in the decision to use J\&T services was caused by minimal promotion.

One of the promotional strategies that have been carried out by PT Garuda Nusaantara (J\&T Express) in Pekanbaru is to use a promotional strategy Public Relations (public relations) in the form of a Fun Walk (healthy walk). By inviting the public to take part in the Fun Walk so that the people of Pekanbaru know about J\&T Express. However, the promotions carried out are still not optimal, because the promotions are only carried out with a frequency of one day so that PT Garuda Nusantara (J\&T Ekspress) is still not in demand by the people of Pekanbaru.

Promotion is a marketing activity that seeks to spread information, influence or persuade and remind the target market of the company and its products to be willing to accept, buy, and be loyal to the products offered by the company concerned. In addition, promotion is also a one-way flow of information or persuasion designed to direct a person or organization to actions that create exchanges in marketing [1]. The main purpose of promotion is to provide information, attract attention and subsequently have an effect on increasing sales. A promotional activity if implemented properly can influence consumers about where and how consumers spend their income. Promotion tries to make demand not elastic] [2]. A promotional strategy is a plan that makes optimal use of the promotional elements: advertising, public relations, personal selling, and sales promotion. [3] In addition there are several achievements or benefits regarding promotion, which are as follows: 1. Stimulating enthusiasm of salespeople to sell new products developed or old products, 2. Strengthening sales of old brands, 3. Facilitating the introduction of new products and brands to the world trade, 4. Adding on-self and off-self to merchandise, 5. Neutralizing competitive advertising and sales promotion, 6. Obtaining trial purchases from consumers, 7. Maintaining current users by encouraging repurchases, 8. Increasing usage products by loading consumers, 9. Winning competition by loading consumer capital, 10. Strengthening advertising [4].

The stages in the consumer purchasing decision process can be described in five stages, namely: 1) Introduction of Needs, is the first stage in the purchasing decision process where consumers recognize a problem or need. 2) Information search, at this stage consumers are motivated to seek more information, consumers can more easily perform active information searches. 3) Evaluation of alternatives, consumers use information to evaluate alternative brands in a set of thoughts. 4) Purchasing needs, this stage consumers actually buy a product. 5) After-purchase behavior, after purchasing a product, consumers will experience a certain level of satisfaction or dissatisfaction [5]. According to Kotler and Armstrong (2010: 179), the purchase decision process includes: 1. Introduction of needs 2. Information seeking 3. Evaluation of alternatives 4. Purchasing decisions 5. Post-purchase behavior [6]. Decision Purchasing is the stage in the buyer's decision-making process where consumers actually buy. Decision making is an individual activity that is directly involved in obtaining and using the goods offered. In addition, the purchase decision is also a selection of two or more alternative purchase decision options, meaning that someone can make a decision, there must be several alternative choices available. [7]

\section{RESEARCH METHOD}

This type of research is descriptive research. Descriptive is research conducted to determine the value of the independent variable, either one or more variables without making comparisons or associations with other variables [8]. When the research was conducted in January 2018, there were 96 samples in this study using random sampling techniques. The sampling technique used the Slovin formula as follows :

$\mathrm{n}=\mathrm{N}$

$\mathrm{N} 1+\overline{(\mathrm{Ne} 2)[9]}$

In the preparation of this research questionnaire was guided by the theory and the assessment was based on the Likert scale [10] Likert scale is used to measure attitudes, opinions, and perceptions of a person or group of people about social phenomena [7], with several alternative answers given the weight of positive and negative ratings, namely a scale range of 1 to 5 . For the analysis used consists of several test tools, namely the validity test, reliability test, $\mathrm{t}$ test, coefficient of determination and simple linear analysis.

\section{RESULTS AND ANALYSIS}

By processing data using SPSS version 20, a simple linear regression equation is obtained which can be seen in the table 2 . 
Table2. Results of Simple Linear Regression Analysis

\begin{tabular}{|c|c|c|c|c|c|c|}
\hline \multicolumn{2}{|c|}{ Model } & \multicolumn{2}{|c|}{ Unstandardized Coefficients } & \multirow{2}{*}{$\begin{array}{c}\text { Standardized } \\
\text { Coefficients } \\
\text { Beta }\end{array}$} & \multirow[t]{2}{*}{$\mathrm{t}$} & \multirow[t]{2}{*}{ Sig. } \\
\hline & & $\mathrm{B}$ & Std. Error & & & \\
\hline 1 & (Constant) & 5,878 & 5,867 & & 1,002 & 0.319 \\
\hline 1 & Promotion & 0.925 & 0.072 & 0.799 & 12,892 & 0.000 \\
\hline
\end{tabular}

Source: SPSS Processed Data, 2018

Based on table 1.2 it can be seen that the regression equation formed is: $\mathrm{Y}=5.878+0.925 \mathrm{X}$

From this equation it can be explained that:

1. The constant (a) of 5.878 states that there is no promotion, so the decision to use is 5.878 .

2. The regression coefficient of 0.925 states that every addition of 1 promotion unit it is predicted that the decision to use will increase by 0.925 . This is because there is a relationship between promotion and usage decisions.

\section{T test results}

The $t$ test is used to test the effect of independent variables and dependent variables individually. Hypothesis testing is done by comparing the value of $t_{\text {count }}$ with $t$ table at $5 \%$ alpha and degree of freeom (df) $=96-2=94$. So that the $t$ table is 1.986. Based on table 5.19, it is known that tcount is 12.892 while ttable is 1.986 (tcount12.892> ttable 1.986). By comparing the value of tcount with ttable, if tcount> ttablethen $\mathrm{H} 0$ is rejected, meaning that the promotion has a significant effect on the Decision to Use J\&T Express services at PT Garuda Ekspress Nusantara Pekanbaru.

\section{Coefficient of Determination (R2)}

The coefficient of determination is used to measure the contribution of the independent variables to the dependent variable. The greater the tolerable coefficient of determination, the better. Guidelines to determine the strength of the relationship from the coefficient of determinationi (R2) can be seen in table 3 , namely:

Table 3. Coefficient of Determination (R2)

\begin{tabular}{ccccc}
\hline Model & R & R Square & Adjusted R Square & Std. Error of the Estimate \\
\hline 1 & $0.799 \mathrm{a}$ & 0.639 & 0.635 & 4,160 \\
\hline
\end{tabular}

Source: SPSS Processed Data, 2018.

Based on table 1.3, it shows that the coefficient of determination (R2) is the R Square value of 0.639 (63.9\%). This means it can be explained that the decision to use $63.9 \%$ is influenced by the promotion at PT Garuda Ekspress Nusantara. Meanwhile, the remaining 36.1\% is influenced by other factors not discussed in this study.

Based on the testing and analysis of the data above, it is found that promotion has an effect on decision-making. It can be seen from the tcount value of 12.8921 which is greater than t table 1.986.maka H0 is rejected at a significance level of $5 \%$ so the conclusion is that promotion has a significant positive effect on the decision to use J\&T services.

\section{CONCLUSION}

Based on the research results on the effect of promotion on the decision to use J\&T Express services at PT Garuda Ekspress Nusantara Pekanbaru, the conclusions are as follows:

a. The results showed that the promotion had a significant influence on the decision to use J\&T Express services at PT Garuda Ekspress Nusantara Pekanbaru.

b. Based on the coefficient of determination (R square) it shows that promotion contributes to the decision to use J\&T Express services at PT Garuda Ekspress Nusantara.

\section{REFERENCES}

[1] K. Supriyono, «Pengaruh Produk, Harga Dan Promosi Terhadap Keputusan Konsumen Dalam Membeli Rumah Pada Perumahan Bukit Semarang Baru (BSB) City Di Semarang», J. Skripsi Ekon. Manaj., pagg. 1-16, 2014.

[2] T. Ariyanti e S. R. Fuadati, «Pengaruh Strategi Promosi Terhadap Penjualan Produk Di Pt . United Indo Surabaya», J. Ilmu Ris. Manaj., vol. 3. No.10, n. 10, pagg. 1-19, 2014.

[3] M. L. Hedynata e W. E. D. Radianto, «Strategi Promosi Dalam Meningkatkan Penjualan Luscious Chocolate Potato Snack», Strateg. Promosi, vol. 1, n. April, pagg. 1-10, 2016. 
[4] N. E. L. Arianty, «Pelanggan Menggunakan Kartu Mentari», J. Ilmu Ekon. dan Stud. Pembang., vol. 13, n. 1, pagg. 101-115, 2013.

[5] D. Agusra, E. O. Lussianda, e Y. Afriyeni, «Strategi promosi untuk meningkatkan kunjungan wisatawan pada agrowisata tenayan raya pekanbaru provinsi riau Promotional strategies to increase tourist visits to agro-tourism in Pekanbaru Raya , Riau Province», Akuntabel, vol. 16, n. 1, pagg. 54-61, 2019.

[6] Nurlina, Milasari, e D. R. Indah, «Pengaruh Kualitas Pelayanan, Harga dan Lokasi terhadap Keputusan Penggunaan Jasa Pengiriman Barang PT. Citra Van Titipan Kilat Kota Langsa», J. Samudra Ekon., vol. 3, n. 1, pagg. 1-8, 2019.

[7] P. Terhadap, K. Pembelian, e F. Annisa, «No Title», vol. VI, n. 2, pagg. 176-187, 2015.

[8] E. O. Lussianda, «Pengaruh kepuasaan mahasiswa terhadap kinerja dosen sekolah tinggi ilmu ekonomi persada bunda pekanbaru The influence of student satisfaction on the performance of high school economics lecturers in pekanbaru», vol. 21, n. 2, pagg. 126-131, 2019.

[9] M. Muin, «Jurnal Economix Volume 5 Nomor 1 Juni 2017», vol. 5, n. 2, pagg. 203-214, 2017.

[10] E. O. Lussianda, «Students' Perception Of Learning Efficiency and Creativity Towards Students Learning Achievement», Curricula, vol. 3, n. 2, pagg. 95-101, 2018. 